\title{
On Protection and Restriction of Private Property Right
}

\author{
Hong $\mathrm{Pu}$ \\ Law school \\ Shandong Univercity of Technology \\ Zibo 255049, China \\ E-mail: law-angel@sohu.com
}

\begin{abstract}
The Real Right Law of the People's Republic of China is the basic law for regulating and protecting the property rights. The Constitution, as the fundamental law, adjusts the property right relationship too. The protection from Constitution is the precondition and base for protecting property right. The Real Right Law is to fulfill the principle of Constitution that ensures citizen's private property right. To protect the property right, Constitution mainly aims at defending the country against outside. Its basic function is to define the country activity. As for the Real Right Law, it is to protect the property right by defining the property in case of invasion of other civil subjects. Both Constitution and Real Right Law offer protection for private property right and also impose restrictions on private property right. That is the national requisition system. This system imposes strict restrictions to private property right. Therefore, it is necessary to set up firm restrictions and constraints on the requisition system. According to the legislation of other countries, we can restrict and constrain this system from three aspects, namely the intention of requisition, the complement standards, and the process, driving the government to realize lawful administration, and protecting the private property right properly.
\end{abstract}

Keywords: Real Right Law of the People's Republic of China, Constitution, Private property right

After several years of preparation, the first Real Right Law in China is finally in effect. It is indeed a formidable process, carrying numerous hardships and disputes, and arousing wide social attentions and extensive participation. The Real Right Law is a basic law for regulating and protecting the property right. It adjusts the property relationships of equal subjects concerning the ascription and utilization of properties. Constitution is the fundamental law of China. It also adjusts the property relationship. The Real Right Law and the Constitution confirm and guarantee the property right from different angles. And they also impose restrictions on the property right, the national requisition system. Because the requisition system serves as strict restrictions on private property right, and in practice, it may be abused by the government, causing unpredictable losses for citizen's private property right, therefore, it is necessary to restrict and constrain the requisition system strictly, driving the government to realize lawful administration. It rightly proves an old saying in German "the wind may blow through it; the rain may enter; but the King of England cannot enter". It is a classical constitutional idea in constitution history. The issue of the Real Right Law undoubtedly strengthens the protection for citizen's property right based on the protection of Constitution.

\section{Protection of Private property right}

The property right is always an important subject in law field. The laws and regulations of property right are not only about civil laws, but, first of all, a constitutional issue. The property right occupies irreplaceable position in the rights system of Constitution and civil laws. The state is responsible for respecting and protecting the property right. In modern constitutional countries, the property right, the right of life, and the right of liberty are the most fundamental rights of citizen, which collectively reflects human basic values and respects. Most countries deprive the property right as one of footstones of constitutional government in Constitutions. "To acknowledge the private property right is a basic condition of stopping or preventing against the state compulsion and despotism. (Hayek, 1997, p174)" In the evolvement of Constitution, the protection of property right has always aroused more attentions of constitutionalists. In 1789, the Declaration of Human Rights in France establishes people's constitutional recognition to the position of property right for the first time. The property right, as a basic human right, wins more highlights in Constitution. To protect the property right actually becomes one of core contents of countries' Constitutions. 
Article 13 of the Constitution of the People's Republic of China (1982) regulates: "The state protects the right of citizens to own lawfully earned income, savings, houses and other lawful property." Article 1 of the Amendment to the Constitution of the People's Republic of China (1988) regulates: "The state permits the private sector of the economy to exist and develop within the limits prescribed by law. The private sector of the economy is a complement to the socialist public economy." Article 16 of the Amendment to the Constitution of the People's Republic of China (1999) makes it clear that "The non-public economies such as the individual economy and the private sector of the economy, operating within the limits prescribed by law, are important components of the socialist market economy." Article 21 of the Amendment to the Constitution of the People's Republic of China (2004) regulates: "The State protects the lawful rights and interests of the non-public sectors of the economy such as the individual and private sectors of the economy. The State encourages, supports and guides the development of the non-public sectors of the economy and, in accordance with law, exercises supervision and control over the non-public sectors of the economy." Article 22 of the Amendment to the Constitution of the People's Republic of China (2004) regulates: "Citizens' lawful private property is inviolable. The State, in accordance with law, protects the rights of citizens to private property and to its inheritance." Apparently, "Present Constitution's protection for private property right is not only limited to or merely lays stress on citizen's lawful incomes, savings, houses, and other life materials, but equalize production materials with life materials. As long as the property is obtained lawfully, it should be respected and protected by the Constitution. Another visible change is that: present Constitution protects the property right, not like the former focusing on the ownership, by claiming that the lawful property is free from invasion, realizing the replacement of 'ownership' with 'property right' that has rich meanings, and extending the scope of property under the protection of Constitution. It includes not only the real rights, but also credit rights, intellectual property rights, inheritance rights, stock rights, the use right of state-owned land, and other modern new rights. In a textual sense, the Constitution (1982) and successive Amendments follow the principle of protecting socialist common property. Meanwhile, it enhances the protection for private property right continuously, absorbing citizen's private property into the protection of Constitution.” (Hongchang Jiao, 2006, p40)

The protection of Constitution for property right is fulfilled by establishing the constitutional position of property right, realizing the property right actually, and making up relevant standards and process as state basic institution and value system (Dayuan Han, 2006, p31). The Constitution is the fundamental law of China. It has the uppermost validity of law. Then, the protection of Constitution is the precondition and basis for property right protection. On one hand, the Constitution can protect private rights. On the other hand, the Constitution indirectly protects private rights by its child laws ------civil laws. But under certain special circumstance, the Constitution can also protect private rights directly. Therefore, the private rights have to depend on the protection of Constitution (Zhiwei Tong, 2006, p17). The Real Right Law is an important sector of civil law system, which makes the civil rights established by Constitution specific and operational, offering details and adjustments to Constitution that confirms and protects the property right of citizens, legal entities, and other organizations. Undoubtedly, the adjustment object of the Constitution and the Real Right Law is the same ----- social economic (property) relationship (Zheng Pang \& Wei Wu, 2006, p33). The Real Right Law is a basic law that regulates and protects the property right. In the aspect of property right protection, the Constitution and the Real Right Law are interconnecting with close association. The Constitution regulates the principle of property right protection and offers a general protection. The Real Right Law details and enhances the scope and contents of property right protection. In addition, the Constitution and the Real Right Law cover different fields. Concerning the property right protection, the Constitution aims at defending against invasions from other countries. Its basic function is to confine the state behavior, define citizens' private spaces where the government should not enter as will. To keep the state out of the door is a powerful barrier that stops the state power invading private spaces. In contrast, the Real Right Law is to protect the property right by defining the border of property in case of mutual invasion between citizens. It protects the relationship in a private scope and forbids the illegal invasion of one private space to another. To keep the evil private subject out of the door is also an important guaranty for citizens' property right (Long Li \& Liantai Liu, 2003, p40, 43).

\section{Restriction of private property right}

Any right is under the restriction of law. An absolute right without any restriction does not exist. The private property right is not an exception. Along with the development of capitalism, in governance the bourgeois realizes that unrestricted property right is not complete good for the whole society. So, they take the property right as social obligation, what is a new theory. A French Duguit is the main representative of social obligation theory. After entering 20th century, based on the social obligation theory, most countries add articles about private property right restriction into Constitution besides protection. The Weimar Constitution in Germany (1919) is the first one that has articles about private property right restriction.

The restriction is mainly about the requisition for private property. According to the Fourth Amendments to the Constitution of the People's Republic of China, the state, in accordance with the law, can requisite the land for the sake of public interests. The Constitutions of other countries have relevant articles concerning the requisition system. Therefore, the requisition is a kind of public right of government approved by the Constitution. No matter whether the 
owner of property agrees to sell private property or not, the government can deprive private property in accordance with the law. The requisition is basic constitutional concepts and also national basic legal system. As an integrated lay system, it concerns different law sectors. It has the character of civil purchase and also the character of administrative activity, concerning the relationship between citizens and government, property right and administrative power. Therefore, the property requisition is always taken as grave constitutional issues, and also basic civil law ------ the adjustment object of Real Right Law.

Requisition is lawful and strict restriction on private property right. The extensiveness and liberty of administrative power may harm citizens' property right. Therefore, it is necessary to constrain the requisition system. Conversely, this constraint serves as powerful protection for private property right, defending against the government taking private property by force.

According to the legislation of other countries, we can restrict and constrain this system from three aspects, namely the intention of requisition, the complement standards, and the process.

Firstly the intention of requisition is------ public interests. Only for the sake of public interests, can government requisites private property. What are public interests? At present, there is no specific legal definition. But in theory, a universal recognition is that all social members benefit from public interests directly, such as public safety, mass health, morals, peace, stability, laws, and regulations. The Article 48 in the consulting version (by Professor Huixing Liang) of 'Real Right Law' (draft) says: "Public interests include roads transportation, public sanitation, disaster prevention and cure, science and cultural education causes, environment protection, protection of cultural relics, historic sites, and sceneries, protection of land with public water sources and investigation, frosts protection, and other public interests regulated by the state law.

Secondly, compensations for requisition should follow the principle of justice. The compensation is the most fundamental condition that restricts state requisition, and also the primary guaranty for private property. According to German "equal public burden theory", the state should establish citizen obligations based on justice under any circumstance. As some citizens or one citizen bears more obligations than others under the same circumstance due to the state behavior, the state should adjust and balance the unbalanced obligations. Because the state behavior should benefit all social members, the society should undertake the losses caused by the state behavior. By means of taxation, the state can compensate certain citizen or some citizens for their losses. Then, a new just mechanism will be resumed between all citizens and victims (Yi Fan, 2001, p104). The Declaration of Human Rights in France and the Constitution of the United States strictly forbid the requisition for property right without compensation.

The standards of compensation usually follow the "justice principle". Some countries requires for "complete" compensation, some "justice or fairness" compensation, and some "proper and reasonable" compensation. Some countries regulate the compensation time: in advance or in time. The Constitution of the Republic of Chile (1980) offers most detailed and specific articles about compensation for requisition.

Thirdly, the requisition process is ------ due process of law. Process of law is the most effective way to restrict and stop the abuse of powers. The due process of law derives from England ancient "natural justice" principle. Experiencing the practice of Constitution of the United States, the due process of law tends to be perfect. It expands from the juridical field toward the administrative field and even the legislation field, imposing overall restrictions on state behavior. Concerning the property right protection, the core of Constitution of the United States is the Fifth Amendments: "nor be deprived of life, liberty, or property, without due process of law". And the fourteen Amendments for the states: "nor shall any State deprive any person of life, liberty, or property, without due process of law". According to the requirements of due process, the requisition should firstly have legislation basis, including not only substantive law but more procedural law. Then, offer opportunities and places for people claiming for their rights. Related subjects should listen to the advices. Finally, the juridical institution should control the last process.

\section{The Real Right Law's restriction on the government}

In recent years, lots of disputes over land requisition happen in China. And there are even blood events among farmers, residents, civil servants, and developers. Many reasons contribute to this fact. One of important reasons is the imperfect requisition system in China.

Firstly, the public interests are unclear. All requisitioned lands are for "state construction". Surely some requisitioned lands are used for building up public facilities, or setting up economic development zones and residential houses according to the overall programming of national economy and social development. But quite lots of requisitioned lands are used for business purposes. The requisition system is abused. Why does the state abuse the requisition system? Reasons are various. Tremendous commercial interests serve as one of fundamental reasons. The state requisitions the use right of lands from farmers or residents at a lower compensation price, and sells to developers at a market price. By this way, the state can get satisfying price differences. Why not? However, the tremendous price differences hurt the interests of farmers or residents. It is not allowable in a legal society and constitutional country. An English John Locke 
said: "But though men, when they enter into society, give up the equality, liberty, and executive power they had in the state of nature, into the hands of the society, to be so far disposed of by the legislative, as the good of the society shall require; yet it being only with an intention in every one the better to preserve himself, his liberty and property; the power of the society, or legislative constituted by them, can never be supposed to extend farther, than the common good; but is obliged to secure every one's property. (John Locke, 1983, p71)"

Secondly, the little and untimely compensation for requisition leads to serious unjust result. Many citizens who have been requisitioned of lands only get little compensations or even nothing, and live a hard life. As a result, it will trigger lots of social problems.

Thirdly, the requisition process is questionable. For example, as programming for an economic zone in certain district of Nanning, not any procedure or notice goes public before the requisition. They just ask farmers to sign their names on a paper. After signing names, farmers must move out. Although these farmers have ownership certificates of houses, these certificates are nothing but useless papers in front of requisition. Tracing the cause of requisition, it is one word of certain governor.

The state frequently invades citizens' property right in practice. No examination system for the requisition behavior, the defects of requisition process, and the arbitrary behavior of the state institutions, impose the great harm on the property right. Therefore, it is necessary to set up restrictions, strengthen the definition of public interests, prevent against the infinite extension of public interest, perfect the requisition process further, and enhance the afterwards supervision.

Before the issue of the Real Right Law, the central and local governments have issued a series of regulations on requisition and removal. However, due to the weak validity and stability, these regulations may be abused in practice. The issue of the Real Right Law undoubtedly offers powerful measures for solving the requisition issue. Article 42, 43, and 44 of the Real Right Law of the People's Republic of China clearly regulates that the government should fulfill lawful administration and protect citizens' private property right.

The issue of the Real Right Law is a milestone in China's legislation process. This law is named as "the basic law of market economy". Its issue will exert fundamental effects on state behaviors. Professor Liming Wang, the President of the Civil Law Society of China Law Society, the Director of the School of Law of Renmin University of China, the main drafter of the Real Right Law, has said, in an interview with a reporter of People's Daily, "The property right, the right of life, and the right of liberty are the three basic rights of citizens. The Real Right Law is not only a basic law that maintains the state basic economic system and protects citizens' property right, but also an important civil law that regulates state administration and ensures citizens' property right. In executing public powers, administrative institutions should build up a consciousness of real right and lay stresses on protection of private property right. For example, when the police fulfill duties, they are forbidden to enter citizens' residences as will, without lawful authorization or in accordance with due process. City administration institutions can manage or punish some illegal commercial behaviors. But they should not damage the properties of violators. One of standards for lawful administrative behavior is whether it respects citizens' basic property right established by the Real Right Law. (Zhiyong Pei, 2007, p13)" The Real Right Law has influential effects on administrative management. It definitely establishes the ascription and utilization of properties, and the scope of private property right. On the other side, it regulates the public power of administrative institutions and the civil servants. As a "backbone" law, the Real Right Law impacts the state administrative behavior at multiple aspects. It puts forward new requirements for the way of administrative management. Administrative institutions should not merely rely on administrative ways in executing their management rights. Administrative guidance, administrative encouragements, administrative contracts, and mother modern management methods and humanism execution methods should be applied more widely. Emphasize on the supervision and service function of administrative institutions. To sum up, the Real Right Law is a basic civil law that regulates the property right. It makes the principle of Constitution specific, driving the state to fulfill lawful administration. The Real Right Law and the Constitution together construct a safeguard for private property right.

\section{References}

Fan, Yi. (2001). Constitutional comparative research on the property requisition policy in China and western countries. Global Law Review. No.Spring. p104.

Han, Dayuan. (2006). Some constitutional issues caused by the dispute over the Real Right Law of the People's Republic of China (Draft). Law Science. No.3. p31.

Hayek. Translated by Deng, Zhenglai. (1997). The Constitution of Liberty. Beijing: SDX Joint Publishing Company. p174.

Jiao, Hongchang. (2006). Analyze the constitutionality of Real Right Law of the People's Republic of China (Draft). Law Science. No.3. p40.

John Locke. (1983). The Second Treatise of Government. Beijing: The Commercial Press. p71. 
Li, Long \& Liu, Liantai. (2003). Function and cooperation of Property Rights in Constitution and Civil Law. Studies in Law and Business. No.6. p40, 43.

Pang, Zheng \& Wu, Wei. (2006). a theoretical response to the challenge of constitutionality of draft of Property Law. Journal of Nanjing Normal University (Social Science Edition). No.6. p33.

Pei, Zhiyong. (2007). Actualize Real Right Law of the People's Republic of China, is the government ready? People's Daily. Apr. $4^{\text {th }} \cdot$ p. 13 .

Tong, Zhiwei. (2006). How the Real Right Law of the People's Republic of China (Draft) passes the Constitution -----comment on the dispute over unconstitutionality and constitutionality caused by a public letter. Law Science. No.3. p17. 